\title{
Study of Several Stages of Maturity and Storage Temperature on Color Changes and Shelf Life of Mangosteen (Garcinia mangostana L.)
}

\author{
Inanpi Hidayati Sumiasih ${ }^{1,3}$, Roedhy Poerwanto ${ }^{1,2} \&$ Darda Efendi ${ }^{1,2}$
}

\begin{abstract}
${ }^{1}$ Agronomy and Horticulture Department, Faculty of Agriculture, Bogor Agricultural University Jl. Meranti, IPB Darmaga Campus, Bogor 16680, Indonesia

${ }^{2}$ Center for Tropical Horticulture Studies (PKHT) Baranangsiang Campus of IPB, JI. Raya Pajajaran, Bogor 16144

${ }^{3}$ Agrotechnology Program, Faculty of Bioindustry, and Trilogi University, Jakarta. Jl. TMP. Kalibata No. 1, Jakarta 12760 Indonesia
\end{abstract}

\section{Abstract}

This study aims to investigate effect of several maturity stage at harvest and storage temperature to mangosteen color changes and shelf life during storage. The research used Completely Randomized Design of two factors. The first factor was the fruit maturity stage at harvest consisting of: Maturity Stage-1 (mostly at 104 days after anthesis day after harvest (DAA), fruit skin color was yellowish green with a little bit of red specks), Maturity Stage-2 (at 106 DAA, fruit skin color was reddish yellow with red specks spread evenly near sepals), Maturity stage-3 (at 108 DAA, fruit skin color was reddish yellow with red specks all over) and Maturity Stage-4 (at 110 DAA, fruit skin color was evenly red). The second factor was storage temperature of $15^{\circ} \mathrm{C}$ and room temperature. The result of harvesting mangosteen at Maturity Stage 1 could maintain skin color longer than at Maturity Stage 2, 3, and 4. Mangosteen that were harvested at Maturity Stage 1 and 2, combined with storage temperature of $15^{\circ} \mathrm{C}$ could maintain fruit quality up to 30 days after harvest and could be used for export market. While harvesting at Maturity Stage 3 could maintain fruit quality up to 25 days after harvest and Maturity Stage 4 up to 20 days after harvest. Harvesting at Maturity Stage 4 followed by $15{ }^{\circ} \mathrm{C}$ storage temperature and all Maturity stages combined with room temperature storage could be used for local market.

\section{Article History}

Received 25 January 2019

Accepted 24 June 2019

Keyword

Fruit color,

Horticultural

commodities,

Queen of tropical fruits,

Shelf life

\section{Introduction}

Fruit freshness during storage is determined by the correct harvest stage and storage condition. The information in the correct harvest stage is needed by mangosteen farmers, local trader and exporter in effort to keep the produce fresh and prolong the shelf life. Mangosteen fruit usually is harvested by Indonesian farmers in various harvest stage, from when the skin color is greenish yellow with red to blackish purple complexion. After harvested, the fruit color that is purplish red changes quickly into blackish purple. To get the 
best quality of mangosteen, harvest should be done in stage when fruit color is randomly bright with pink to red specks all over the fruit.

After harvest and in storage, changes will happen in mangosteen in its skin color, sepals and aril. That is due to the fruits still undergo physiological process even after detached from its tree. Those changes may deplete mangosteen quality. Therefore, there is a need of effort to slow down the physiological process of mangosteen fruit. Efendi (2005) stated that the effort to prolong mangosteen storage time could be done by using controlled storage atmosphere, coating materials and low storage temperature.

Incorrect harvest stage and storage of mangosteen fruit can make the fruit skin harden faster and deplete its quality. Manurakchinakorn et al. (2016) stated that Mangosteen fruit at ripeness stage 6 (purple black pericarp) has a very limited storage life and deteriorate rapidly. Sartika and Poerwanto (2010), stated that the problem occurred in mangosteen storage in room temperature for two weeks was hardened fruit skin. Prolonging storage time of mangosteen fruit and keep its quality can be done by keeping the fruit in low temperature and harvest the fruit at the right maturity stage. Low temperature storage lower respiration and transpiration rate, thus can prolong storage time with minimal weight loss, keep its quality and resulted in higher value in the market. When mangosteen fruit harvested past the maturity stage with incorrect storage, mangosteen fruit can quickly lost quality, i.e. sepals turn brown and hardened fruit skin before it reaches consumers. Therefore, research in the correct harvest stage and storage temperature to prolong storage is needed so mangosteen fruit can reaches domestic and international consumers with intact quality.

\section{Materials and Methods}

Mangosteen fruit was from mangosteen plantation in Tanggamus Regency, Lampung. The research was conducted in Postharvest Laboratory, Agronomy and Horticulture Department, Bogor Agricultural University. Materials used were Maturity Stage indicators, phenolphthalein indicator (PP), $\mathrm{NaOH} 0.1 \mathrm{~N}$ solution and distilled water. Tools used in this research were; Erlenmeyer flask, analytic scale, cool storage, hand refractometer, pipette, volumetric flask, color reader and thermometer.

This research used Completely Randomized Design with two factors. First factor was mangosteen maturity stage at harvest that was consisted of four stages that were: Maturity Stage-1 (mostly at 104 days after anthesis (DAA), fruit skin color was yellowish green with a little bit of red specks), Maturity Stage-2 (at 106 DAA, fruit skin color was reddish yellow with red specks spread evenly near sepals), Maturity stage-3 (at 108 DAA, fruit skin color was reddish yellow with red specks all over) and Maturity Stage-4 (at 110 DAA, fruit skin color was evenly red). Second factor was storage temperature that consisted of two levels that were: storage temperature of $15^{\circ} \mathrm{C}$ and room temperature $\left(28^{\circ} \mathrm{C}\right)$. Manurakchinakorn el al. (2014) stated that Mangosteen is sensitive to low temperature and develops chilling injury $(\mathrm{Cl})$ when stored at temperature below $13{ }^{\circ} \mathrm{C}$. If the result of analysis of variance showed significant difference at F-test with alpha of $5 \%$ or $1 \%$ post-test of Duncan Multiple Range Test was conducted.

Destructive observations were conducted every five days for 30 days after harvest (DAH). Study by Anggraeni (2008) stated that mangosteen fruit that was harvested at mature stage and stored at room temperature could only last for 15 days after harvest, while storage at temperature of $15{ }^{\circ} \mathrm{C}$ could make mangosteen fruit lasted for 20 days after harvest. The observations were total titratable acid (TTA) (\%), fruit skin water content, fruit skin color 
appearance, optimum consumption point, organoleptic test, color scoring, and mangosteen fruit sepal freshness.

\section{Results and Discussion}

Total Titratable Acid (TTA)

Total Titratable Acid (TTA) content showed not much of a difference in amongst all treatments (showed in Table 1). At the early storage time, TTA of mangosteen was around $0.60-0.74 \%$. Generally, TTA value of every treatment was declined especially after $10 \mathrm{DAH}$. The decline of TTA was possibly because the organic acids in the fruit was used as substrate in fruit respiration during ripening. Wills and Tirmazi (1981) stated that organic acids are the energy reserve for fruit and will decrease during increasing metabolic activity at fruit ripening. Study by Suketi (2011) showed that TTA content of papaya was decreased as fruit maturity level was increased, showed by fruit skin that was became yellow. That happened because TTA was depleted along with fruit ripening.

Table 1. TTA content of mangosteen at several maturity stage and storage temperature during storage

\begin{tabular}{llllllll}
\hline \multirow{2}{*}{ Treatment } & 0 & 5 & 10 & 15 & 20 & 25 & 30 \\
\cline { 2 - 8 } & $0.74 \mathrm{a}$ & 0.69 & 0.68 & 0.54 & 0.40 & 0.24 & 0.20 \\
\hline Stage 1 & $0.68 \mathrm{ab}$ & 0.64 & 0.66 & 0.55 & 0.38 & 0.24 & 0.19 \\
Stage 2 & $0.67 \mathrm{ab}$ & 0.65 & 0.65 & 0.54 & 0.40 & 0.24 & 0.19 \\
Stage 3 & $0.60 \mathrm{~b}$ & 0.61 & 0.63 & 0.54 & 0.37 & 0.23 & 0.14 \\
Stage 4 & 0,66 & 0,66 & $0.67 \mathrm{a}$ & 0.55 & 0.47 & 0.48 & 0.36 \\
Temperature of $15^{\circ} \mathrm{C}$ & 0,69 & 0,65 & $0.64 \mathrm{~b}$ & 0.54 & - & - & - \\
Room temperature & 0,69 &
\end{tabular}

Notes: Numbers followed by the same letter in the same column showed insignificant difference based on DMRT 1\%. - was the fruit that skin hardened with dried aril (rotten).

\section{Mangosteen Aril Appearance}

Results of observation on aril appearance started from 0-30 DAH showed in Figure 1 and 2. At harvest (ODAH) at $15^{\circ} \mathrm{C}$, mangosteen that was harvested at Maturity Stage 1 and 2 had aril that could not be separated with endocarp and had a lot of yellow sap, while at 5 DAH mangosteen could already be consumed. At the end of storage, mangosteen that was harvested at Maturity Stage 3 and 4 had hollow space between aril and endocarp. Endocarp color was brownish and aril color was unappealing. While fruit that was harvested at Maturity Stage 1 and 2 could still able to be consumed in the end of storage and appeared to be in good condition with white aril and fresh endocarp.

Anjaritha et al. (2019) about Mangosteen (Garcinia mangostana L.) is a tropical fruit with high market value but has short shelf-life during postharvest handling. At room temperature storage, the limit of consumers acceptability at all harvest Maturity Stages was $15 \mathrm{DAH}$. At $20 \mathrm{DAH}$ all mangosteen from all Maturity Stages had already rotten and could not be consumed (aril was brown and endocarp was dried and brown). Study by Sumiasih et al. (2011) showed that mangosteen with $15^{\circ} \mathrm{C}$ storage temperature and harvested at Maturity Stage 1 and 2 had the most favorable taste at $20 \mathrm{DAH}$ and could be kept for $30 \mathrm{DAH}$. 
Storage temperature of $15^{\circ} \mathrm{C}$

(a)

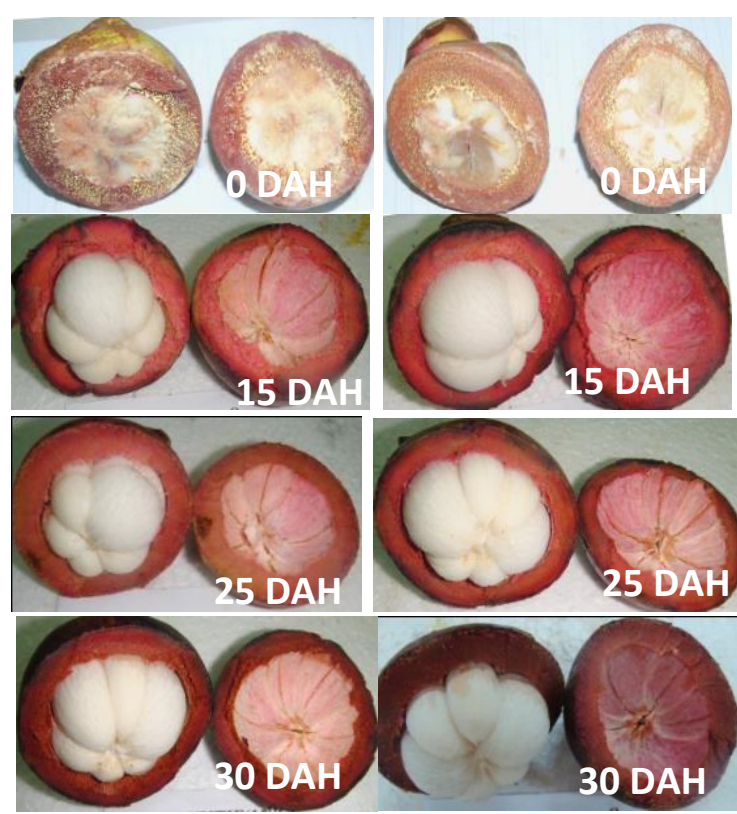

(c)

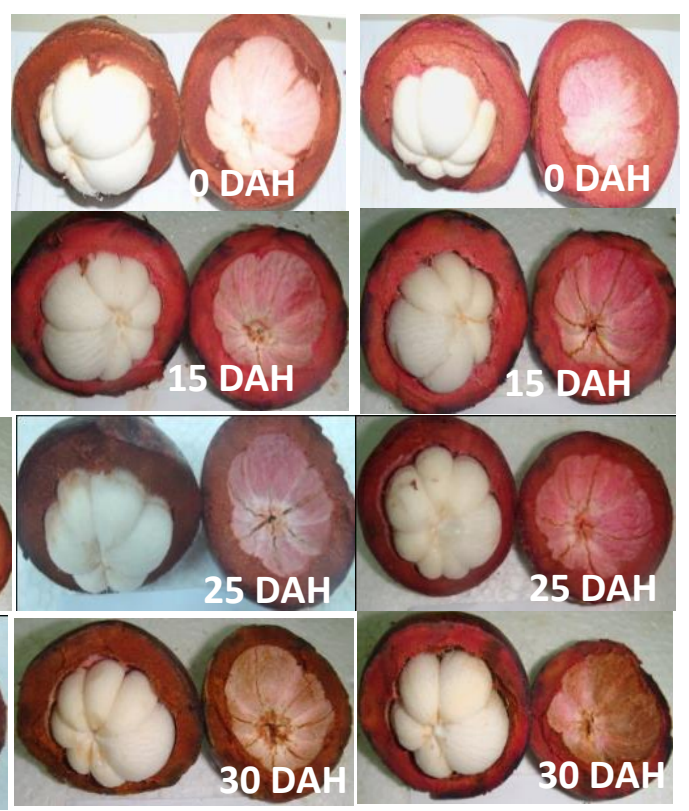

Figure 1. The appearance of mangosteen aril from 0 DAH to $30 \mathrm{DAH}$ : (a) Maturity Stage 1, (b) Maturity Stage 2, (c) Maturity Stage 3, and (d) Maturity Stage 4 at storage temperature of $15^{\circ} \mathrm{C}$

Room Temperature Storage

(a)

(b) (d)

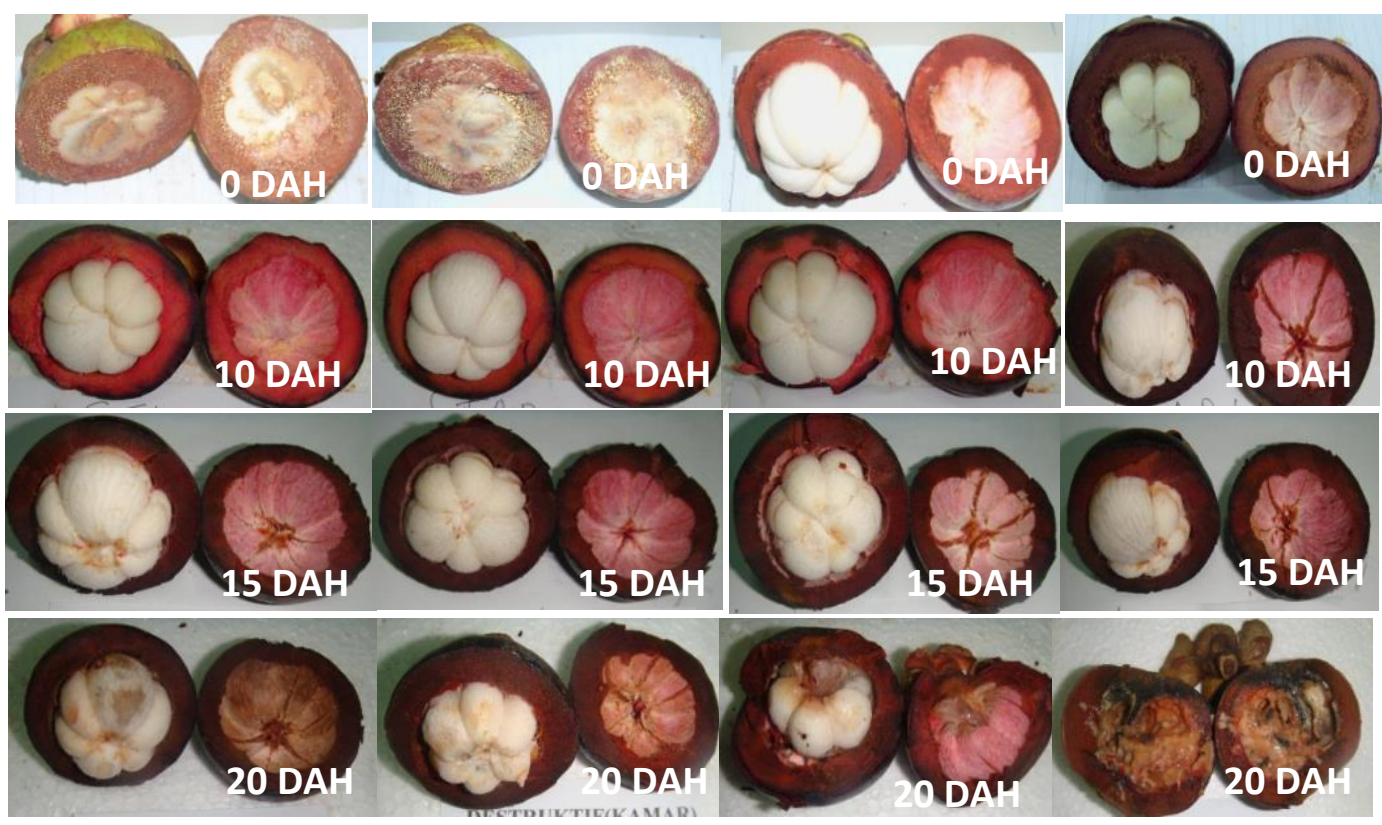

Figure 2. The appearance of mangosteen aril from 0 DAH to $30 \mathrm{DAH}$ : (a) Maturity Stage 1, (b) Maturity Stage 2, (c) Maturity Stage 3, and (d) Maturity Stage 4 at room temperature storage 


\section{Water Content Percentage (\%)}

The combination of Maturity Stage and storage temperature gave significant difference on skin water content (Table 2). In storage, there was changes in mangosteen fruit skin water content. The percentage of mangosteen fruit skin water content from $0 \mathrm{DAH}$ to 13 DAH was not significantly different, while at $20 \mathrm{DAH}$ and $25 \mathrm{DAH}$ showed significant difference between treatments. Mangosteen fruit at Maturity Stage 1 and 2 showed higher skin water content than other treatments.

In storage, mangosteen fruit skin water content was decreased, in storage temperature of $15{ }^{\circ} \mathrm{C}$ and in room temperature. Mangosteen fruit water content generally declined along with longer storage time. This was supported by Sumiasih et al. (2016) about star fruit harvested at several maturity stages and kept in different storage temperature, showed that weight loss could be an indicator of declined quality of horticultural products. Storage at low temperature was the part of post-harvest treatment that could be used to minimize water content loss in star fruit. Weight loss percentage in low temperature storage $\left(18^{\circ} \mathrm{C}\right)$ was slower compared to room temperature storage.

Mangosteen at storage temperature of $15{ }^{\circ} \mathrm{C}$ showed higher water content than at room temperature. This showed that lower storage temperature can supress water loss in fruit. If water loss can be suppressed, it was expected that weight loss also declined and increase mangosteen fruit skin resistance so the freshness and appearance of mangosteen can be maintained. According to Kader (1992), water loss content in mangosteen was due to respiration and transpiration process that could be the reason for fruit shrinkage, because not only it affected directly in quantitative loss (weight loss) but also loss in quality and appearance of crispiness and juice content. Aizat et al. (2019) about mangosteen have rich in potent bioactive compounds, such as xanthones, and is known to possess pharmacologically important anti-inflammatory and antitumor properties.

Table 2. Mangosteen fruit skin water content at several maturity stages and storage temperature

\begin{tabular}{|c|c|c|c|c|c|c|c|}
\hline \multirow{2}{*}{$\begin{array}{l}\text { Combination of } \\
\text { treatments }\end{array}$} & \multicolumn{7}{|c|}{ Fruit skin water content (\%) } \\
\hline & 0 & 5 & 10 & $\begin{array}{l}15 \\
\text { (DAH) }\end{array}$ & 20 & 25 & 30 \\
\hline Stage $1,15^{\circ} \mathrm{C}$ & 78.02 & 76.89 & 70.57 & 68.19 & $69.46 \mathrm{a}$ & $68.38 \mathrm{a}$ & 68.96 \\
\hline Stage $2,15^{\circ} \mathrm{C}$ & 78.49 & 75.96 & 69.82 & 66.95 & 66.19 a & $67.43 \mathrm{a}$ & 68.67 \\
\hline Stage $3,15^{\circ} \mathrm{C}$ & 77.88 & 75.44 & 67.18 & 65.53 & $62.57 a b$ & $62.51 \mathrm{a}$ & 64.63 \\
\hline Stage $4,15^{\circ} \mathrm{C}$ & 78.85 & 77.76 & 66.58 & 64.94 & $62.43 \mathrm{bc}$ & $61.82 \mathrm{ab}$ & 60.29 \\
\hline Stage 1 , room & 78.23 & 75.16 & 62.02 & 59.59 & $58.76 \mathrm{~cd}$ & $43.36 \mathrm{c}$ & 32.00 \\
\hline Stage 2, room & 77.68 & 74.48 & 63.00 & 60.91 & $57.20 \mathrm{e}$ & $41.39 \mathrm{~cd}$ & 31.36 \\
\hline Stage 3, room & 78.10 & 76.73 & 61.52 & 59.35 & $48.06 \mathrm{f}$ & $22.88 \mathrm{e}$ & 26.17 \\
\hline Stage 4, room & 78.55 & 76.41 & 62.70 & 56.79 & $39.25 \mathrm{~g}$ & $21.72 \mathrm{e}$ & 22.56 \\
\hline
\end{tabular}

Note: The numbers followed by the same letter in the same column showed no significant difference based on DMRT at $1 \%$. 
Mangosteen Fruit Sepal Color and Freshness Scoring

The effect of maturity stage and storage temperature to sepal color was shown at Figure 3.
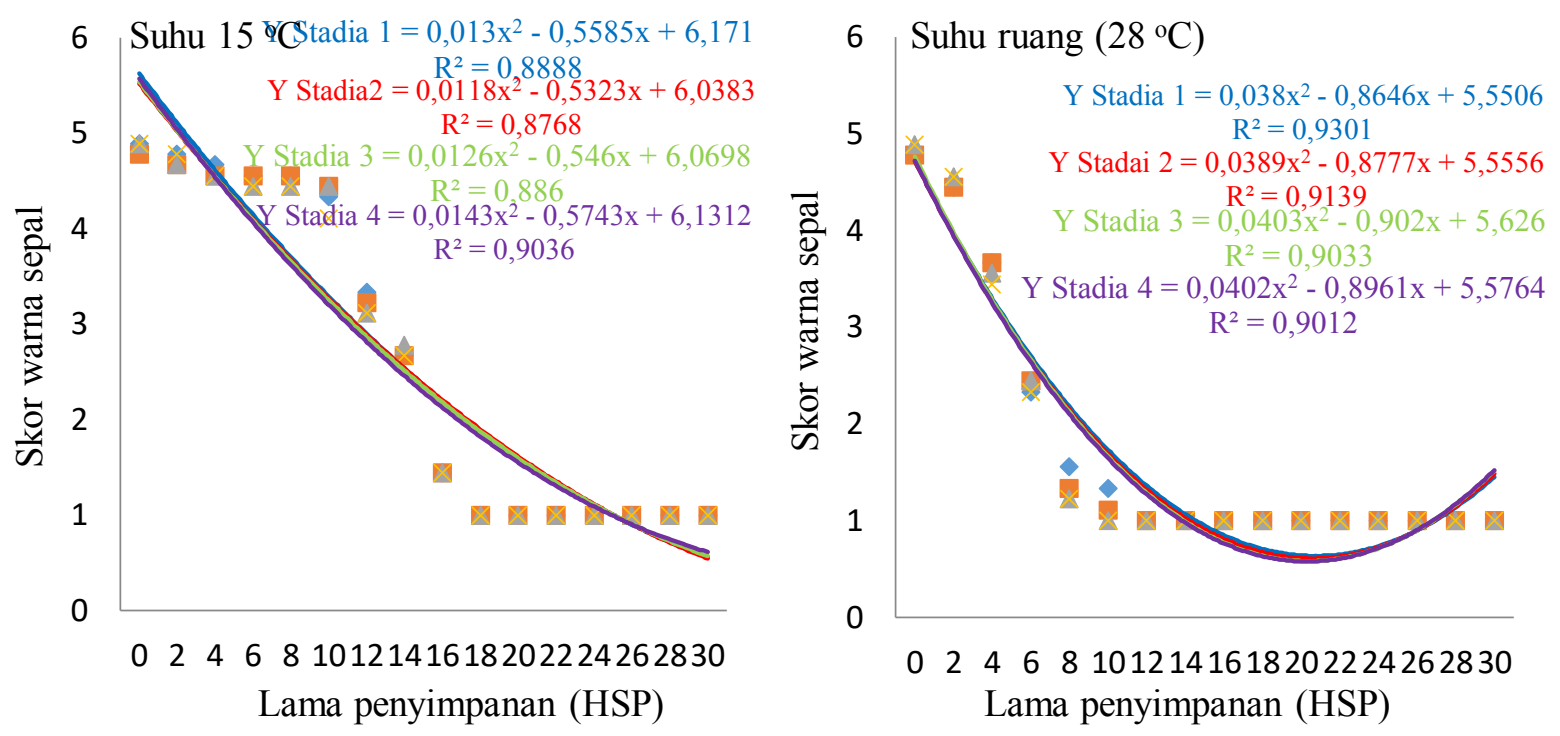

Figure 3. Mangosteen sepal color score at several maturity stages and room temperature

The effect of maturity stage and storage temperature to mangosteen sepal freshness score was shown at Figure 4.

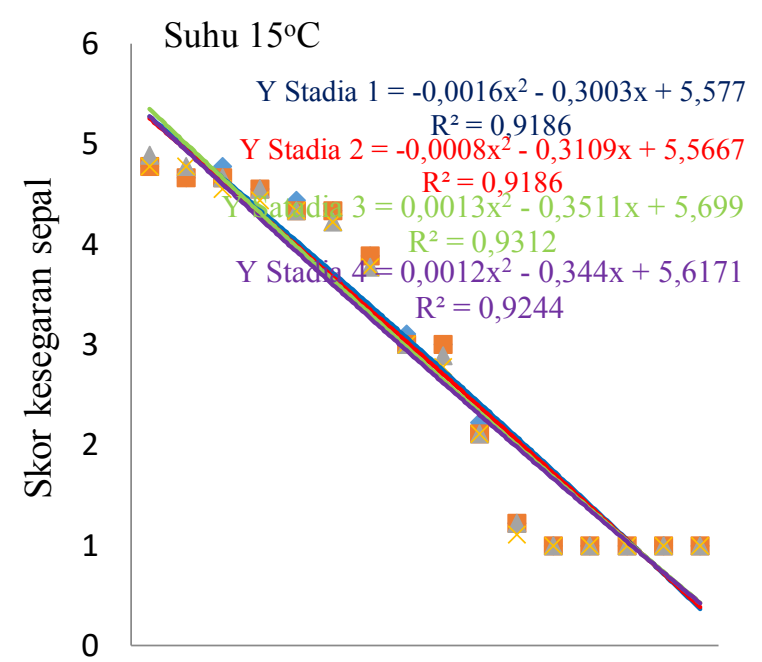

024681012141618202224262830 Lama penyimpanan (HSP)

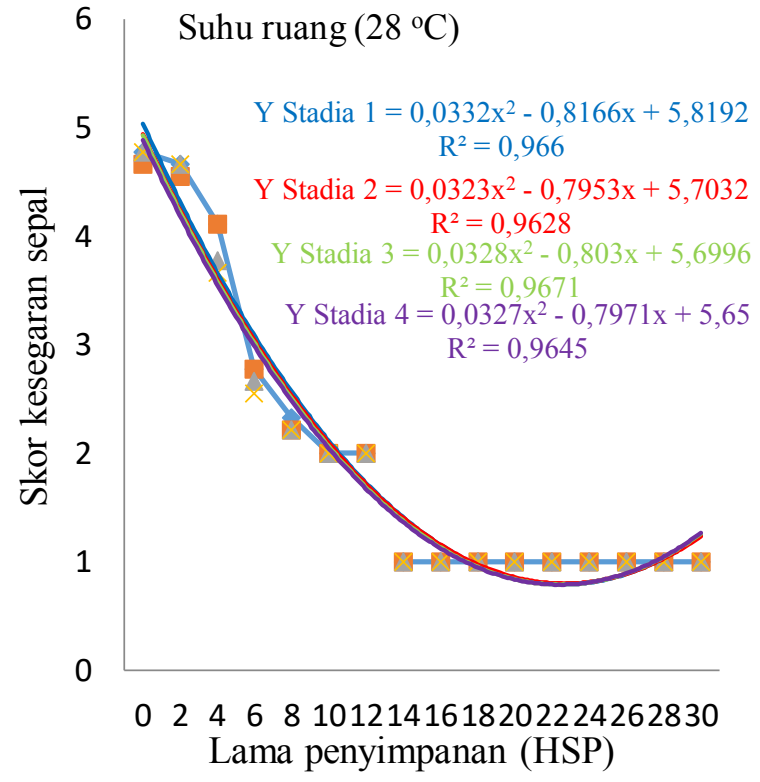

Figure 4. Mangosteen fruit sepal freshness from several maturity stages and storage temperature

Color and Freshness of mangosteen fruit sepal had effect on mangosteen quality during storage. Fresh mangosteen fruit had green sepal and then turned into brown, indicating the fruit had lost its freshness. Mangosteen fruit that stored at storage temperature of $15{ }^{\circ} \mathrm{C}$ had lower decrease in sepal color and freshness score. Color and freshness of 
mangosteen fruit sepal at all maturity stages that were kept in $15^{\circ} \mathrm{C}$ declined at $12 \mathrm{DAH}$ and continue to decline gradually up to $20 \mathrm{DAH}$ and until the end of storage. While mangosteen fruit sepal at all maturity stages that were kept at room temperature started to decline at 6 DAG and continue to slowly decline up to $12 \mathrm{DAH}$ and until the end of storage.

Study results from Suyanti et al. (1999) showed that mangosteen that harvested when the skin color was green with a bit of purple (104 days after anthesis) had sepal that kept its freshness up to $6 \mathrm{DAH}$. Ismadi et al. (2010) showed that after storage mangosteen had several changes in appearance. Characteristics for fruit that suitable for consumptions are black brownish skin fruit, there is still yellowish green specks at the sepal, has not loss its weight and the skin are not hardened.

\section{Mangosteen Fruit Skin Appearance}

Observation result of mangosteen fruit skin color started at harvest (0 DAH) until the end of storage ( $30 \mathrm{DAH}$ ) at $15{ }^{\circ} \mathrm{C}$ (Figure 5) and at room temperature (Figure 6). According to Kader 2003, after harvest and during storage, the mangosteen will canges color which is one of the parameters of fruit maturity.

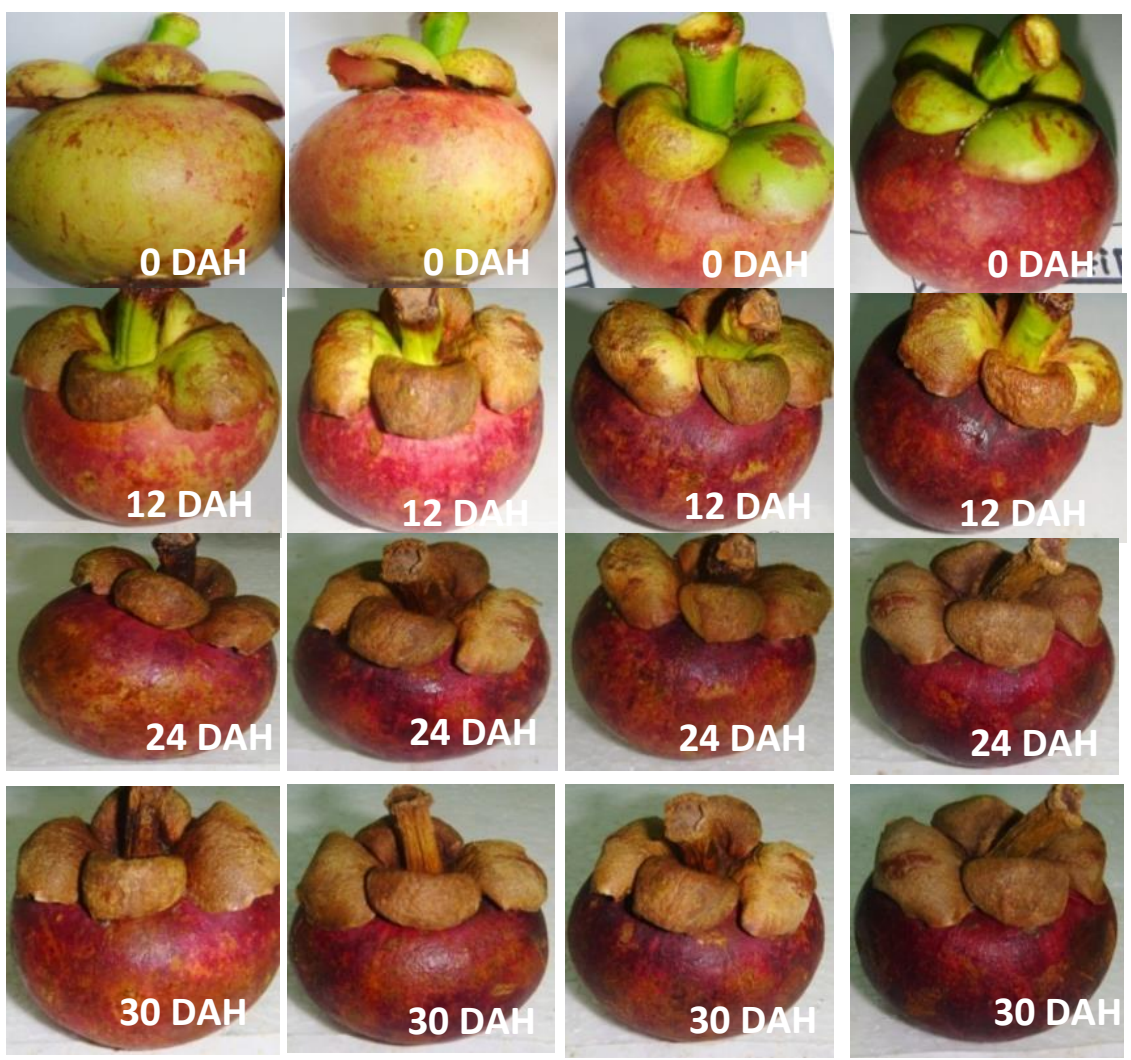

Figure 5. Mangosteen fruit skin appearance frim 0 DAH to 30 DAH: (a) Maturity Stage 1, (b) Maturity Stage 2, (c) Maturity Stage 3, and (d) Maturity Stage 4 in storage temperature of $15^{\circ} \mathrm{C}$

Figure 5 showed that mangosteen at all maturity stages in storage temperature of 15 ${ }^{\circ} \mathrm{C}$ was able to keep its skin color than mangosteen kept in room temperature. According to Sumiasih et al. 2017, skin color was one of the external attributes for horticulture products, for example at their research of maintaining citrus skin color. Skin color had important role in consumers' decision making to purchase. 
Mangosteen that was stored at $15{ }^{\circ} \mathrm{C}$ (30 DAH) had red brownish skin color for maturity stage 1 , red purplish skin color for maturity stage 2 and 3 and black purplish skin color for maturity stage 4 . While mangosteen that was stored at room temperature had the same skin color appearance at $6 \mathrm{DAH}$ that were black purplish.

(a)
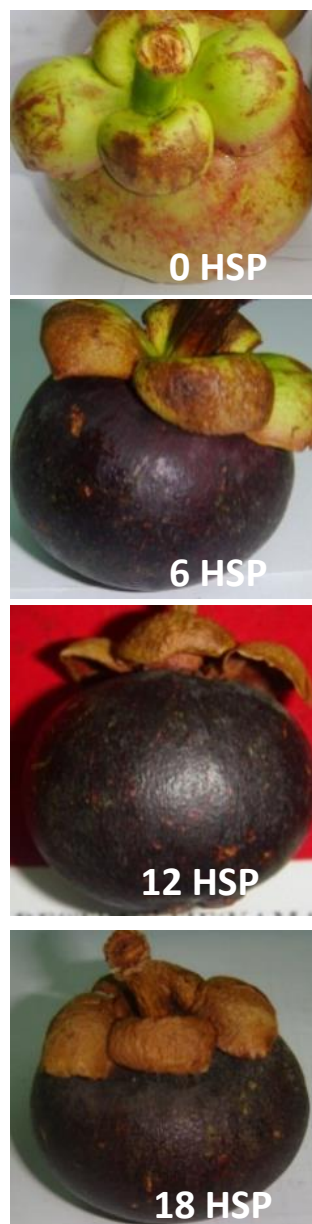

(b)
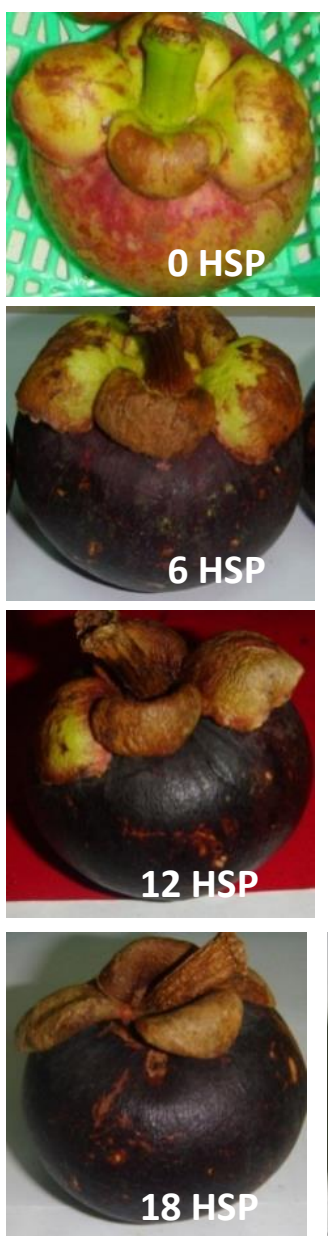

(c)
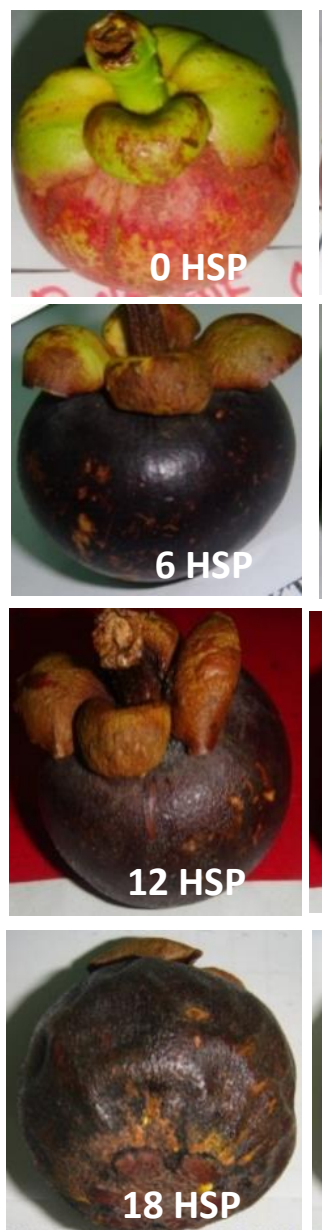

(d)
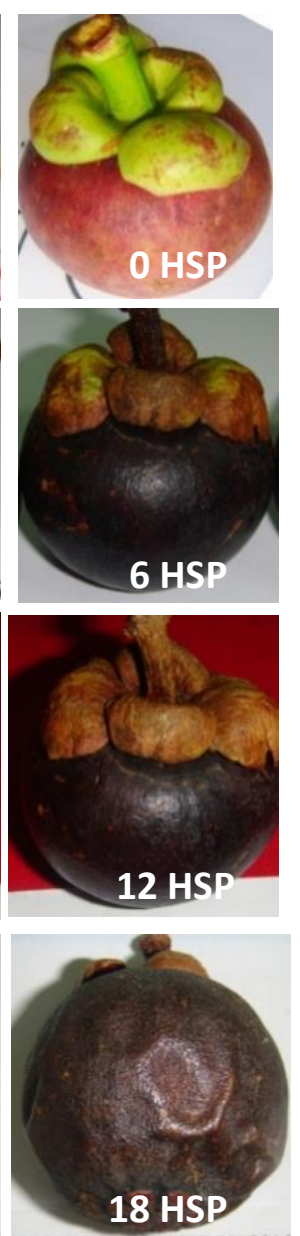

Figure 6. Mangosteen fruit skin appearance frim 0 DAH to $30 \mathrm{DAH}$ : (a) Maturity Stage 1, (b) Maturity Stage 2, (c) Maturity Stage 3, and (d) Maturity Stage 4 in room temperature storage

Consumers acceptance limit of mangosteen at Maturity Stage 1, 2, 3, and 4 in storage temperature of $15{ }^{\circ} \mathrm{C}$ were at $30 \mathrm{DAH}, 30 \mathrm{DAH}, 25 \mathrm{DAH}$, and $20 \mathrm{DAH}$, respectively, while in room temperature at all maturity stages was $20 \mathrm{DAH}$. The optimum consumption point of mangosteen that was kept at $15^{\circ} \mathrm{C}$ was $20 \mathrm{DAH}$ (stage 1 and 2) and $10 \mathrm{DAH}$ (stage 3 and 4). As for mangosteen that was stored in room temperature at stage 1 was $15 \mathrm{DAH}$ and at stage 2,3 , and 4 was $10 \mathrm{DAH}$.

\section{Conclusions}

The result showed that harvesting mangosteen at Maturity Stage 1 could kept skin color, sepal color and freshness longer than at Maturity Stage 2, 3 and 4. Mangosteen that was harvested at Maturity Stage 1 and 2 with storage temperature of $15{ }^{\circ} \mathrm{C}$ could maintain fruit quality (appropriate for consumption) for 30 days after harvest and could be used for export market. Mangosteen harvested at Maturity Stage 3 and Maturity Stage 4 could be 
stored up to $25 \mathrm{DAH}$ and $20 \mathrm{DAH}$, respectively. At Maturity stage 4 with storage temperature of $15{ }^{\circ} \mathrm{C}$ and at all maturity stages with room temperature was appropriate for local market. Castro et al. 2012 about the maximum storage period for mangosteen at $25^{\circ} \mathrm{C}$ is two weeks; while storage at $13^{\circ} \mathrm{C}$ can guarantee the conservation of this fruit for 25 days.

\section{References}

Aizat, W.M., Ahmad-Hashim, F.H. and Jaafar, S.N.S., 2019. Valorization of mangosteen, "The Queen of Fruits," and new advances in postharvest and in food and engineering applications: A review. Journal of Advanced Research.

Anggraeni, W., 2008. Penggunaan bahan pelapis dan plastik kemasan untuk meningkatkan daya simpan buah manggis (Garnicia mangostana L.) [skripsi]. Agronomy and Horticulture Department, Faculty of Agriculture, Bogor Agricultural University.

Castro, M.F.P.P.M., Anjos, V.D.D.A., Rezende, A.C.B., Benato, E.A. and Valentini, S.R.D.T., 2012. Postharvest technologies for mangosteen (Garcinia mangostana L.) conservation. Food Science and Technology, 32(4), pp.668-672.

Efendi, D., 2005. Rekayasa genetika untuk mengatasi masalah-masalah pascapanen. Bul. Agron. 33 (2) 49-56.

Ismadi., Poerwanto, R., Efendi, D., Bintang, M., Muchtadi, D and Sutrisno., 2010. Studi pengerasan buah manggis selama penyimpanan. National conference on horticulture.

Kader, A.A., 2003. Mangosteen recommendation for maintaining postharvest quality.http//rics.undavis.edu/postharvest2//produce/producefacts/fruitmangostee n.shtml.

Kader, A.A. 1992., Quality and safety factors: definition and evaluation for fresh horticulture crop. University of California Division of Agriculture and Nature Resources. Oakland.

Manurakchinakorn, S., Nuymak, P. and Issarakraisila, M., 2014. Enhanced chilling tolerance in heat-treated mangosteen. International Food Research Journal, 21(1).

Manurakchinakorn, S., Chainarong, Y. and Sawatpadungkit, C., 2016. Quality of mangosteen juice colored with mangosteen pericarp. International Food Research Journal, 23(3), p.1033.

Parijadi, A.A., Ridwani, S., Dwivany, F.M., Putri, S.P. and Fukusaki, E., 2019. A metabolomicsbased approach for the evaluation of off-tree ripening conditions and different postharvest treatments in mangosteen (Garcinia mangostana). Metabolomics, 15(5), p.73.

Sartika, R and Poerwanto, R., 2010. Pengaruh suhu dan kelembaban udara terhadap shelf_life dan karakteristik buah manggis (Garcinia mangostana L.) selama penyimpanan. Agronomy and Horticulture Department, Faculty of Agriculture, Bogor Agricultural University.

Suketi, K. 2011. Studi morfologi bunga, dan perkembangan buah sebagai dasar pengendalian mutu buah pepaya IPB [Disertation]. Agronomy and Horticulture Department, Faculty of Agriculture, Bogor Agricultural University.

Sumiasih, I.H., Octaviani, L., Lestari, D.I. and Yunita, E.R., 2016. Studi Perubahan Kualitas Pascapanen Buah Belimbing Dengan Beberapa Pengemasan dan Suhu Simpan. Agrin: Jurnal Penelitian Pertanian, 20(2).

Sumiasih, I.H., Poerwanto, R., Efendi, D., Agusta, A. and Yuliani, S., 2017. The Analysis of $\beta$ cryptoxanthin and Zeaxanthin using HPLC in the Accumulation of Orange Color on Lowland Citrus. International Journal of Applied Biology, 1(2), pp.37-45. 
Suyanti, S., Roosmani, A.B.S.T and Sjaifullah., 1999. Pengaruh tingkat ketuaan terhadap mutu pascapanen buah manggis selama penyimpanan. J. Hort. 1(9):51-58.

Wills, R.B.H and Tirmazi, S.I.H., 1981. Inhibition of ripening of avocado with calcium. School of food tecnologi, New South Wales University. Australia. 